\title{
LA PRIMERA OBRA DOCUMENTADA DEL MAESTRO ESCULTOR JOSÉ NARANJO
}

\author{
POR José Roda PEÑa
}

La biografía y personalidad artística del escultor José Narạjo nos son prácticamente desconocidas. Tan sólo se han publicado un par de noticias que relacionan su actividad con la del insigne imaginero utrerano Francisco Antonio Gijón (1653-¿1720?). En ambos casos, José Naranjo, “maestro escultor”, actúa como fiador de Gijón en las escrituras de concierto de sendas andas procesionales para Cofradías sevillanas: las del misterio del Despedimiento de Cristo el 5 de mayo de $1688^{1}$, y las del Crucificado del Amor el 16 de junio de 1694; en esta última consta su vecindad en la collación de San Marcos ${ }^{2}$.

En base a los anteriores testimonios, Bernales Ballesteros dedujo que José Naranjo pudo colaborar con Gijón en algunos de los trabajos citados ${ }^{3}$. Lo que no cabe duda, como veremos a continuación, es que perteneció a su círculo de seguidores, entre los que se cuentan Bartolomé García de Santiago, o su propio hermano Miguel Ruiz Gijón.

La obra que presentamos es, por el momento, la primera y única que acredita la dedicación escultórica de José Naranjo. Se rata de la efigie de San Roque que se venera en la parroquia hispalense de San Nicolás de Bari, en un retablo fechado hacia 1760 ubicado en la nave de la Epístola ${ }^{4}$. Dicha imagen fue contra-

1. HERNÁNDEZ DÍAZ, José: Materiales para la Historia del Arte Español en "Documentos para la Historia del Arte en Andalucía”. T. II. Sevilla, 1928, p. 223.

2. CUELLAR CONTRERAS, Francisco de Paula: "Notas inéditas sobre el Paso del Santísimo Cristo del Amor" en La Pasión. Sevilla, 1956, s.p.

3. BERNALES BALLESTEROS, Jorge: Francisco Antonio Gijón. Sevilla, 1982, pp. 97 y 111.

4. Es el segundo retablo del lado de la Epístola, comenzando por los pies del templo; estuvo consagrado a San Benito, cuya imagen figura en el ático. Con posterioridad, en su hornacina principal acogió la venerada talla de la Virgen del Subterráneo, que desde hace unos diez años recibe culto 
tada con la Hermandad de Nuestra Señora de las Nieves y San Crispiniano en 1692, tal como lo prueba el siguiente recibo:

"Digo yo, Josephe Naranjo, que resebí del Sr. Xriptóbal Lopes como Mayordomo de la Hermandad de Nuestra Señora de las Niebes y Señor San Chrispiniano, setecientos reales de bellón por un Señor San Roque que se consertó en seiscientos y cincuenta reales, y los otros cincuenta por componer los asientos de los santos y por lo qual me doi por contento y pagado en dies y ocho de agosto del año de 1692. Josephe Naranjo (rúbrica)" 5.

Con respecto a la citada Hermandad, sabemos que estaba integrada por oficiales zapateros de la ciudad, contando en el antiguo templo renacentista de San Nicolás con retablo propio ${ }^{6}$. Este altar, desaparecido tras el estreno del actual edificio tardobarroco, se había concertado el 19 de agosto de 1689 con el fecundo ensamblador Cristóbal de Guadix (1650-1709) por una suma de tres mil reales ${ }^{7}$; el finiquito, que ahora damos a conocer, se firmó el 18 de septiembre de 1690:

"Digo io, qristóbal de guadis, que e resebido de Josefe Carrasco $i$ de Francisco Talabán i de Juan Miguel i de Alonso Garzía, maiordomo de la

en el manifestador del altar mayor; fue entonces cuando se trasladó a este lugar la escultura de San Roque. El retablo, profusamente adornado con rocallas, consta de mesa de altar, banco, cuerpo principal compartimentado en tres calles por estípites y coronamiento. A los lados de la hornacina que cobija al citado San Roque, figuran sobre peanas las efigies dieciochescas de San Fernando y San Hermenegildo. En los muros laterales figuran dos lienzos de formato mixtilíneo con sendas escenas de la vida de San Benito de Nursia y de su hermana Santa Escolástica.

5. (A)rchivo (G)eneral del (A)rzobispado de (S)evilla. Sección Hermandades. Leg. 95. Libro de Descargo de la Hermandad de Nuestra Señora de las Nieves para este año del Señor de 1688, f. $7 \mathrm{r}$.

6. FALCÓN MÁRQUEZ, Teodoro: "La iglesia de San Nicolás de Bari, de Sevilla" en Archivo Hispalense. Sevilla, 1968, p. 182. En el capítulo X de la Copia de escritura que tuvo lugar con motivo de la reedificación de la iglesia parroquial de San Nicolás de esta ciudad, otorgada por don Juan Basilio de Castañeda en 13 de noviembre de 1758 ante don Dionisio Bravo, se dice que "por cuanto de muchos años a esta parte está fundada en la dicha iglesia parroquial de San Nicolás una Hermandad con el título de Nuestra Señora de las Nieves que es de los oficiales zapateros, de obra prima de esta ciudad, cuya Hermandad tenía el uso de un altar en la misma iglesia que se titulaba de Nuestra Señora de las Nieves, que hoy con el propio nombre existe en la nave del lado de la Epístola en forma de Capilla con su retablo nuevo, declara el otorgante quedó permanente sin novación alguna el dicho uso en favor de la referida Hermandad y reservado su Patronato y propiedad para la enunciada Fábrica".

7. HERNÁNDEZ DÍAZ, José: "Papeletas para la historia del retablo en Sevilla, durante la segunda mitad del siglo XVII" en Boletín de Bellas Artes, n. ${ }^{\circ}$ 3. Sevilla, 1936, p. 10. 
ermandad de nuestra señora de las niebes $i$ de los demás ofiziales $i$ ermanos de la dicha ermandad, trezientos $i$ zinquenta reales de bellón con los quales me acabaron de pagar la dicha cantidad en que se ajustó el retablo que ize para la dicha capilla i me doi por contento i pagado de la dicha cantidad que aora ni en ningún tiempo pueda pedirles nada a la dicha ermandad, ni al dicho Josefe Carrasco ni al dicho Francisco Talabán ni al dicho Juan Miguel, que fueron con los que ize el ajuste i la escritura, lo qual por ser verdad lo firmé en 18 de septiembre de 1690 años. Cristóbal de Guadis (rúbrica)" ${ }^{8}$.

A Lorenzo Vallejo, nacido en Sevilla en $1671^{9}$, se debe el dorado de la anterior máquina retablística, acometiendo su labor entre 1703 y 1704. En el Libro de Cuentas de la Hermandad de Nuestra Señora de las Nieves quedó anotado el siguiente recibo:

"Digo yo Lorenzo Vallejo que reciví de D. Visente Rodríguez, Maiordomo que fue el año pasado de 1703, 1780 reales de vellón por quenta del dorado del retablo; y por consiguiente rezeví del Sr. Cristóbal Ramírez, Maiordomo que fue del año de 1704, 2.380 reales de vellón, con la qual cantidad me acavó de pagar lo ajustado del dorado, que monta 4.100 reales. $Y$ juntamente rezeví treinta y siete reales y medio de vellón que se montó el aliño del retablo y los ángeles, con lo qual me doi por contento y pagado, y por ser verdad lo firmé. Lorenzo Vallejo (rúbrica)" 10 .

Por fortuna, se conservan las dos imágenes cotitulares de esta extinguida Hermandad, que continúan recibiendo culto en un retablo neoclásico del lado de la Epístola ". La de Nuestra Señora de las Nieves, cuya advocación se ha trocado por la de Gracia, es una efigie anónima sevillana de candelero para vestir, fecha-

8. A.G.A.S. Sección Hermandades. Leg. 95. Libro de Descargo de la Hermandad de Nuestra Señora de las Nieves para este año del Señor de $1688, \mathrm{f} .7 \mathbf{r}$. 235.

9. QUILES GARCÍA, Fernando: Noticias de Pintura (1700-1720). Sevilla, 1990, pp. 232-

10. A.G.A.S. Sección Hermandades. Leg. 95. Libro de Descargo de la Hermandad de Nuestra Señora de las Nieves para este año del Señor de 1688, f. 24v. En el f. 25r., correspondiente al año 1704, se anotó que "primeramente cien reales de vellón que pagó a Lorenzo Vallejo por el dorado de las dos molduras que están en dicha Capilla".

11. Con anterioridad, las imágenes de la Virgen de las Nieves, San Crispiniano y San Roque estuvieron ubicadas en el retablo que presidía la Capilla Sacramental. Pasaron a su actual emplazamiento en la década de los años cuarenta, cuando las imágenes titulares de la Cofradía de la Candelaria se trasladaban al citado Sagrario, recién remodelado. 
ble en la primera mitad del siglo XVII; reposa sobre una amplia peana de nubes tachonada por cinco cabezas de querubes. Su rostro, de delicada factura, muestra el hieratismo y la frontalidad de otras imágenes contemporáneas de gloria. Lleva al Niño Jesús en la mano izquierda, y con la otra porta el cetro; otros atributos argénteos son la corona imperial, la ráfaga y la media luna a los pies.

Una extraordinaria calidad en su ejecución muestra la escultura en madera policromada de San Crispiniano, que ha de ser obra de un artista sevillano de primera fila, activo en la primera mitad del Seiscientos. En su mano izquierda sostiene un libro, teniendo mutilados algunos dedos de la diestra. Luce túnica y manto rojos; la primera, abotonada al cuello y ceñida por un fajín azul a la cintura; el segundo cae suelto por la espalda desde el hombro izquierdo. El abigarrado estofado con motivos vegetales ennoblece la presencia del copatrón de los maestros zapateros.

La efigie de San Roque, objeto principal de nuestra atención, es una talla en madera policromada, de tamaño menor al natural (mide 1,05 ms. de alto). Desde el punto de vista estilístico, la obra se enmarca plenamente en el contexto del Barroco dinámico que caracteriza a la escultura hispalense de la segunda mitad del siglo XVII: cabellera de gruesos mechones trabajados a grandes planos, inserción de ojos de cristal, intensidad expresiva, acusado contrapposto, composición del manto en diagonal, etc.

José Naranjo participa, pues, de las corrientes estéticas de su tiempo; no es un artista retardatario, pero tampoco parece probable que innovara en el terreno de las formas, y aún menos en el de los tipos iconográficos. Al ser este San Roque la única obra que hasta ahora se le ha documentado, no es posible advertir los grafismos que pudieron ser característicos de su labor. Sin embargo, los vínculos con la producción imaginera de Francisco Antonio Gijón son bien palpables: la vehemencia del rostro, animado de una dramática expresión, reforzada por los labios entreabiertos del santo; el tratamiento de las manos, elegantes y nervudas; amplios golpes de gubia en los pliegues de la indumentaria, etc.

Desconocemos si Naranjo contó con la ayuda de un "pintor de imágenes" o si policromaría sus propias obras; en el caso del San Roque que nos ocupa, se aplicó una encarnadura mate de acertados matices tostados y un suntuoso estofado que enriquece el aspecto de sus vestidos, a la vez que señala la noble cuna del santo de Montpellier.

Su iconografía es la tradicional: sostiene en la mano izquierda el báculo con la calabaza que indica, al igual que las veneras sobre la esclavina azul, su condición de peregrino; con la diestra se recoge el corto sayal verde, para mostrar la úlcera abierta de su pierna izquierda, que fue curada milagrosamente por un ángel en un bosque cercano a Piacenza. No le acompaña, como suele suceder en otras ocasiones, la simpática figura del perro que le asistía diariamente en su 
retiro, llevándole un trozo de pan. Es bien sabido que San Roque fue invocado durante siglos en toda Europa como protector contra la terrible epidemia de la peste ${ }^{12}$.

12. Santos Sanadores. Barcelona, 1948, pp. 37-40; FERRANDO ROIG, Juan: Iconografía de los Santos. Barcelona, 1950, p. 240. 


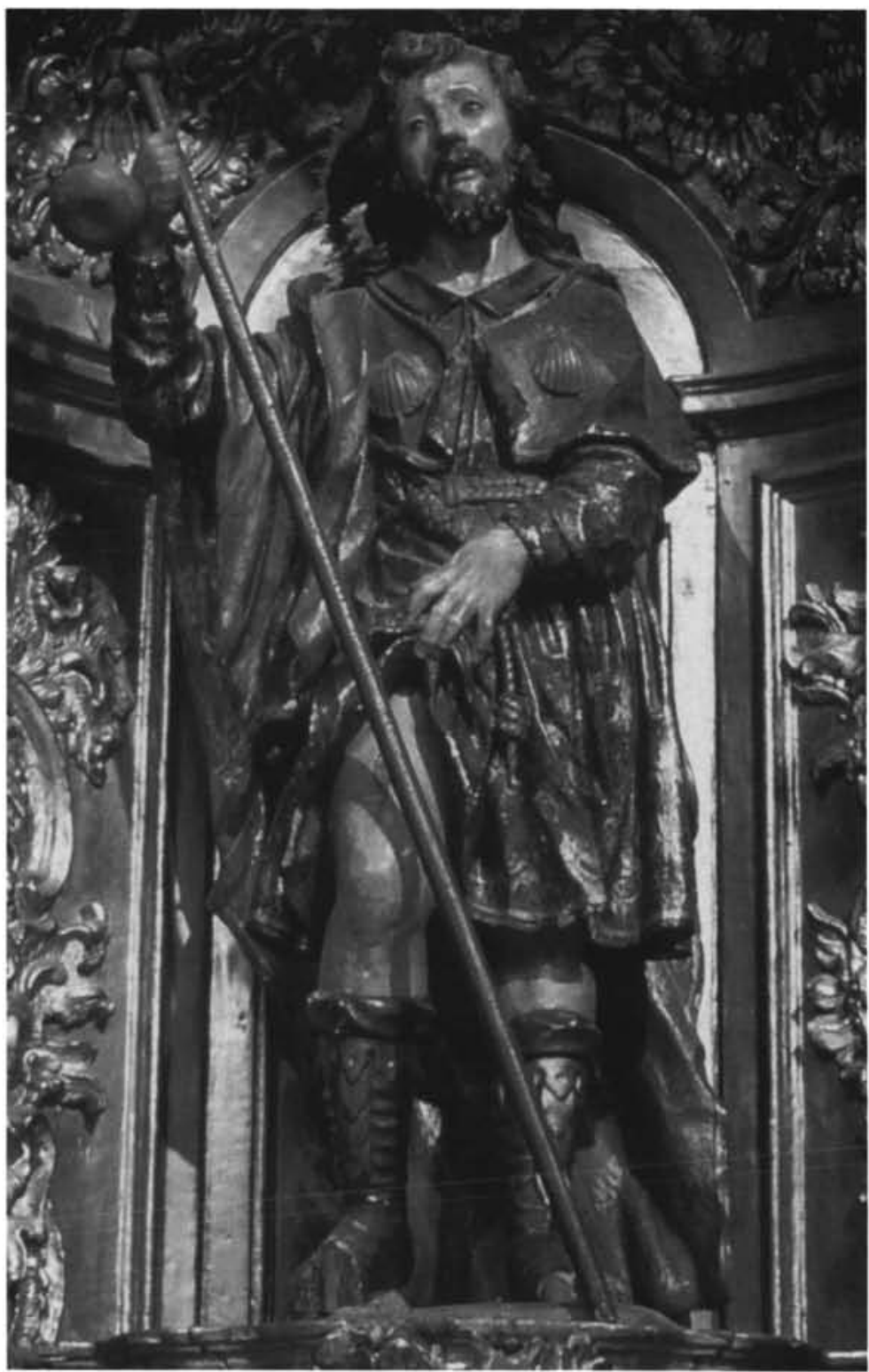

Lám. 1.

José Naranjo, San Roque, 1692.

Parroquia de San Nicolás de Sevilla. 


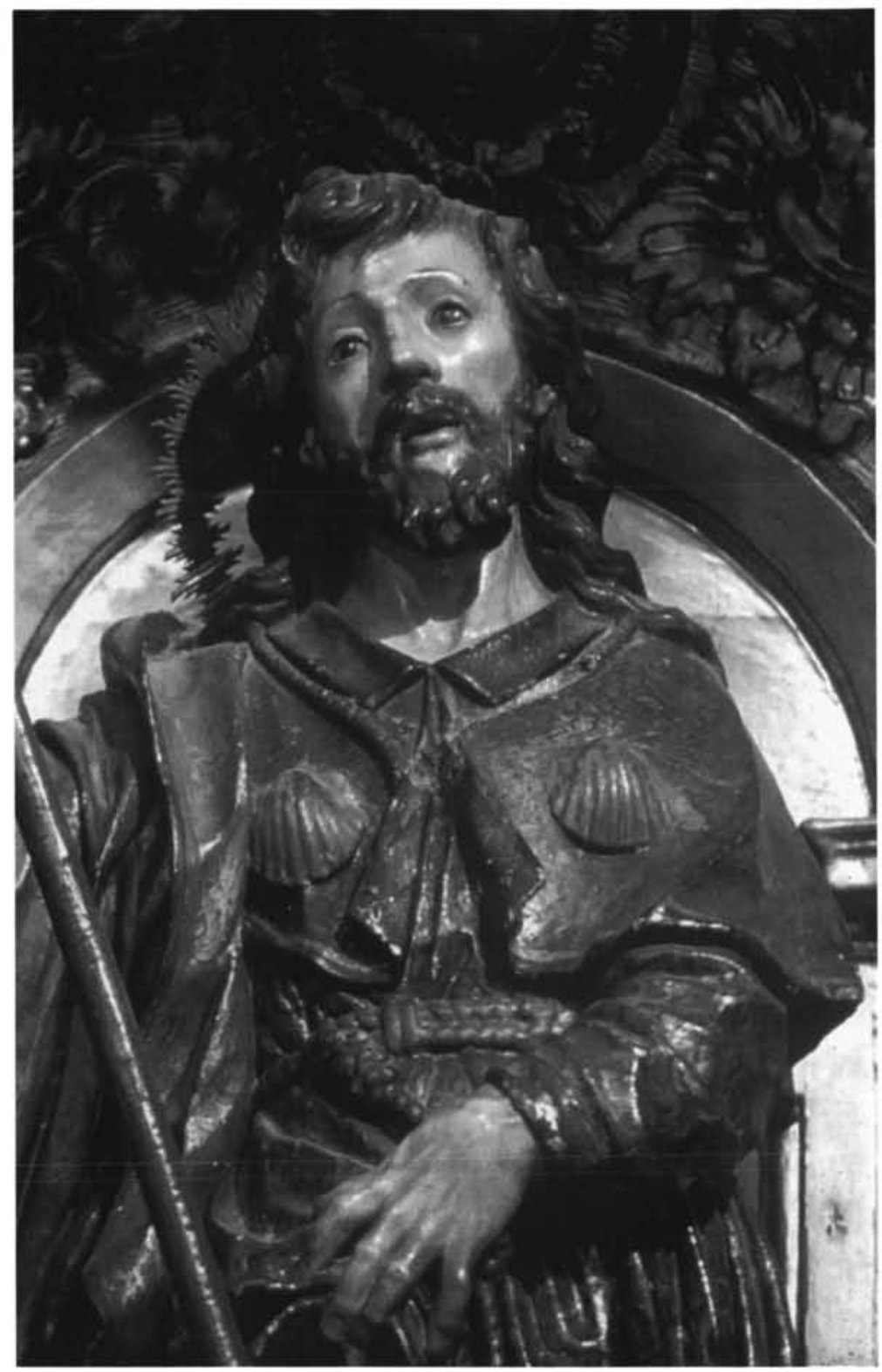

Lám. 2.

José Naranjo, San Roque, 1692.

Parroquia de San Nicolás de Sevilla. 